\title{
Estudio de la fluencia de una calcarenita: la Piedra de San Julián (Alicante)
}

\section{Study of creep behavior of a calcarenite: San Julián's stone (Alicante)}

\author{
$\underline{\text { V. Brotóns }}{ }^{(*)}$, S. Ivorra(*) J. Martínez-Martínez ${ }^{(*, * *)}$, R. Tomás ${ }^{(*)}$, D. Benavente ${ }^{(*, * *)}$
}

Recepción/Received: 10-XII-12

Aceptación/Accepted: 7-V-13

\section{RESUMEN}

La fluencia de las rocas tiene gran importancia en la evaluación del comportamiento a largo plazo de elementos construidos con estos materiales. En este trabajo, se ha caracterizado física y mecánicamente una calcarenita porosa bien conocida localmente como Piedra de San Julián. Se han realizado ensayos de compresión uniaxial de $96 \mathrm{~h}$. a carga constante. Se ha utilizado un modelo de fluencia bien conocido, el Código-modelo CEB-FIP 2010, usado para modelizar otro material pétreo (hormigón). Además, se ha propuesto un modelo reológico. El objetivo principal de este trabajo es investigar la posibilidad de aprovechar la gran experiencia acumulada en el estudio del hormigón, con el fin de obtener un enfoque para el comportamiento de la roca, para tiempos de prueba muy largos difíciles de implementar en laboratorio. Se propone una función de fluencia adaptada a la roca estudiada dependiente sólo de sus características elásticas y mecánicas.

Palabras clave: modelo reológico; fluencia; roca blanda; caliza; calcarenita.

\begin{abstract}
Rocks creep has a great importance in the evaluation of the long-term behaviour of elements built with or within these materials. In this work, a porous well-known limestone locally named as San Julián stone has been physically and mechanically characterized. Uniaxial compressive tests for $96 \mathrm{~h}$. at constant stress are carried out. Long-term behaviour has been modelled by means of a well-known creep model, the CEB-FIP Model code 2010, used for modelling other stony-material (i.e. concrete). Furthermore, a rheological model has been proposed. The main aim of this work is to investigate the possibility of exploiting the vast experience accumulated in the study of concrete deformational long-term behaviour in order to obtaining a reasonable approach to the behaviour of the rock, for too long testing times difficult to implement in laboratory. A creep function adapted to the studied rock only dependent on its elastic and mechanical characteristics is also proposed in this work.
\end{abstract}

Keywords: rheological model; creep; soft rock; limestone; calcarenite.

\footnotetext{
(*) Universidad de Alicante (Alicante, España).

(**) Unidad Asociada CSIC- Universidad de Alicante (Alicante, España).
} 


\section{INTRODUCCIÓN}

Los materiales rocosos pueden sufrir altas deformaciones a largo plazo cuando se someten a carga constante (fluencia). El conocimiento del comportamiento en fluencia de las rocas es crucial para determinar el factor de seguridad de los túneles, edificios históricos con grandes muros de sillería, y en general en todos los tipos de obras en las que la roca actúa como un componente estructural o como apoyo de cargas de cimentación (zapatas, estribos de presas, etc.). Este fenómeno ha sido estudiado y modelado por varios autores, aunque el volumen de referencias existentes sobre rocas es mucho menor que para los fenómenos de fluencia en hormigón. Algunos estudios se centran en el desarrollo de técnicas para la construcción y mantenimiento de túneles, utilizando modelos reológicos o ecuaciones constitutivas $(1,2)$. Otros investigadores estudian el impacto de la fluencia en macizos rocosos mediante la medición de las deformaciones en las excavaciones y proponen modelos para reproducir este comportamiento (3) o, basándose en estudios en laboratorio de muestras de rocas intactas, proponen modelos reológicos y predicen las deformaciones de fluencia (4). Propuso (5) un modelo constitutivo para el comportamiento en fluencia de los llamados geomateriales, en el que la deformación por fluencia se atribuye a cambios macroscópicos en la microestructura de los materiales (cambios mecánicos, físicos y químicos). De manera similar, pero relacionando la deformación diferida sólo con la generación de microgrietas, (6) analiza la deformación volumétrica por medio de un modelo constitutivo. Existen trabajos centrados en el estudio de la influencia del tipo de prueba (stress-path) (7). Estudió (8) la fluencia lenta causada por cargas muy bajas. Analizó (9) la influencia de los ciclos de cargadescarga. Finalmente (10), estudió los cambios en las características micro-mecánicas de las rocas bajo cargas de gravedad, que afectan directamente al fenómeno de la fluencia. Otro enfoque consiste en el estudio de las rocas como material de construcción. En este sentido (11), estudió la deformación a largo plazo en la mampostería de edificios históricos. En cuanto a mineralogía y propiedades físicas, (12) ha mostrado que las rocas de estructura cristalina (ígneas o metamórficas) presentan rotura frágil incluso con bajos niveles de carga, con un comportamiento viscoelástico en el que la componente viscosa tiene muy poco peso. En las rocas sedimentarias en general la viscosidad adquiere mayor importancia, dando lugar a mayores deformaciones a más largo plazo (13). La porosidad es esencial, (14) distingue entre parte dura (matriz) y parte blanda (poros, fracturas, fisuras...). La parte blanda está sujeta a grandes deformaciones. Las deformaciones de la parte dura son pequeñas, y dentro del rango que permite su estudio con las relaciones tensión-deformación usuales en ingeniería. El efecto del contenido de agua o grado de humedad se ha estudiado en $(15,16)$ mostrando que afecta de manera importante tanto a la resistencia como

\section{INTRODUCTION}

Rock materials can suffer high long-term deformations when subjected to constant compressive load (creep). The knowledge of creep behaviour of rocks is crucial for determining the safety factor of tunnels, historic buildings with large ashlar walls, and generally in all types of works in which the rock acts as a structural component or is the support of foundation loads (e.g. foundations, dam abutments, etc.). This phenomenon has been studied and modelled by several authors, although the volume of existing literature on rocks is much lower than for concrete creep phenomena. Some studies are focused on developing techniques for the building and maintenance of tunnels, using rheological or constitutive models $(1,2)$. Other researchers study the impact of creep on rock masses by measuring the deformations in excavations and proposing a model for reproducing their behaviour (3), or based on laboratory studies of intact rocks samples and rheological models for predicting the creep deformations (4). (5) Proposed a constitutive model for creep behaviour of the so called geomaterials, in which it is deemed as the consequence of macroscopic changes in the materials microstructure (i.e. mechanical, physical and chemical changes). Similarly, but simply relating the deferred deformation with the generation of micro-cracks, (6) analysed the volumetric deformation by means of a constitutive model. There are several works focused on the study of the influence of the type of test (stress-path) (7). (8) Studied the slow creep caused by very low loads. (9) analysed the influence of the charge-discharge cycles. Finally, (10) studied the changes in the micromechanical characteristics of rocks under gravity loads, which directly affect the creep phenomenon. Another approach consists on the study of rocks as a construction material. In this sense, (11) studied the long-term deformation in the masonry of historic buildings. As mineralogy and physical properties, (12) shows that the crystalline structure of rocks (igneous or metamorphic) exhibit brittle fracture even at low load levels, with a viscoelastic behaviour where the viscous component has little weight. Generally in sedimentary rocks viscosity is a more determining factor, leading to greater deformations in the longer term (13). Porosity is essential, (14) distinguishes between the hard part (matrix) and the soft part (pores, fractures, cracks ...). The soft part is subject to large deformations were compressed. Strains in the hard part are small, and within the range that allows the study of the stress-strain relations usual in engineering. The effect of water content or moisture level has been studied $(15,16)$ showing that significantly affects both the strength and the long term deformation. Weak rocks are more sensitive to the presence of water. The important deformations in dry rock increase markedly. The brittle fracture, they can become ductile 
a la deformación a largo plazo. Las rocas débiles son más sensibles a la presencia de agua. Las deformaciones ya importantes de la roca seca, se incrementan. Las roturas frágiles pueden llegar a convertirse en dúctiles con altos contenidos de agua. La fluencia terciaria se presenta sólo con muy alto contenido en agua en algunos casos (15).

Aunque la mayoría de los estudios citados se desarrollaron bajo condiciones de laboratorio utilizando muestras de roca intactas, hay que señalar que no existe un procedimiento unificado para desarrollar los ensayos de fluencia a largo plazo. Uno de los problemas más comunes en los estudios arriba mencionados es la breve duración de las pruebas de laboratorio y la extrapolación correcta de los resultados obtenidos a la fluencia real sufrida por las rocas.

El objetivo de este trabajo es aprovechar los modelos de fluencia conocidos establecidos para el hormigón (17) y adaptarlos a la roca blanda estudiada con el fin de estimar la fluencia a largo plazo de las rocas.

\section{MATERIALES Y MÉTODOS}

El estudio de la fluencia a largo plazo de las rocas se aplicó a una piedra caliza porosa ampliamente utilizada como material de construcción en la ciudad de Alicante (SE de España). Esta caliza se conoce localmente como Piedra de San Julián. Forma los principales afloramientos de las colinas que rodean el perímetro urbano de la ciudad. Estos afloramientos han actuado como canteras durante siglos y han proporcionado los sillares de los principales edificios históricos de la ciudad. Por otra parte, las líneas de tranvía futuras de la red de transporte público se construyen a través de estas colinas y, por consiguiente, la piedra caliza porosa estudiada constituirá el soporte geotécnico de los túneles del tranvía. De hecho, las muestras estudiadas en este trabajo se obtuvieron a partir de bloques de piedra extraídos de la excavación de la línea de tranvía. Todas estas razones justifican la importancia de obtener un valor fiable de la fluencia a largo plazo de esta roca específica.

Se tomaron rocas de la Serra Grossa, situada en el noreste del casco urbano de Alicante. Las probetas de roca estudiadas en este trabajo se obtuvieron a partir de bloques recogidos de la excavación del túnel del tranvía. Los bloques de roca fueron recogidos justo después de la excavación y se transportaron al laboratorio en donde se extrajeron probetas por medio de un taladro con broca hueca.

El procedimiento fue el siguiente: En primer lugar, se llevaron a cabo ensayos de fluencia a corto plazo de las rocas en el laboratorio. En segundo lugar, la fluencia a largo plazo se calculó a partir de dos modelos diferentes (reológico y Código-modelo CEB-FIP) (17). Este último at high water contents. Tertiary creep occurs only with very high water content in some cases (15).

Although most of the cited studies were developed under laboratory conditions using intact rock samples it should be noted the lack of a unified procedure to develop the long-term creep tests. One of the most common problems in the above listed studies is the brief duration of the laboratory tests and the assumed extrapolation of the obtained results to the real long term creep actually suffered by rocks.

The aim of this paper is to take advance of the wellknown creep models established for concrete (17) and to adapt them to the studied weak rock in order to estimate the long-term creep of rocks.

\section{MATERIALS AND METHODS}

The study of the long-term creep of rocks was applied to a porous limestone widely used as building material in Alicante city (SE of Spain). This limestone is locally known as Piedra de San Julián. It forms the main outcrops of the hills surrounding the urban perimeter of the city. These outcrops acted as quarries for ages and they provided the ashlars for the main historic building of the city. Moreover, the future tram lines of the public transport network of the city are being built through these hills, and consequently, the studied porous limestone will constitute the geotechnical support of the tram tunnels. In fact, the samples studied in this paper were obtained from rock blocks extracted from the excavation of the tram line. All these reasons justify the relevance of obtaining a reliable value of long-term creep of this specific rock.

Samples were taken from the Serra Grossa hill, located at the NE of the urban area of Alicante. Rock samples studied in this paper were obtained from rock blocks collected from the dump of the tram tunnel. The rock blocks were collected just after the excavation and transported to the laboratory where the samples where extracted by means of a drill.

The research procedure was as follows: Firstly, shortterm creep tests were carried out on rock samples in laboratory. Secondly, the long-term creep was calculated from two different models (rheological model and CEBFIP model) (17). This latest model is widely applied to 
modelo se aplica ampliamente a la fluencia del hormigón, y las variables del modelo se han adaptado a las características específicas de las rocas. La comparación entre los resultados obtenidos con ambos procedimientos (pruebas a corto plazo y modelos a largo plazo) permite establecer la deformación de la roca bajo tensión constante en períodos de tiempo muy largos.

Para la realización de los taladros se tuvo en cuenta la orientación de los planos de estratificación en los bloques, de manera que en las probetas cilíndricas obtenidas estos planos de estratificación quedaran perpendiculares al eje de cilindro.

Se obtuvieron 10 muestras cilíndricas de diámetro $54 \mathrm{~mm}$ y $100 \mathrm{~mm}$ de altura para las pruebas petrofísicas y mecánicas (ultrasonidos, porosidad y densidad, resistencia y fluencia a tensión constante). En primer lugar se llevó a cabo la caracterización mineralógica y petrográfica. En segundo lugar, se obtuvo la resistencia de la roca por medio de ensayos de compresión uniaxial (18). En tercer lugar, se llevaron a cabo las mediciones de las deformaciones bajo tensión constante, que se fijó en el $45 \%$ de la tensión previamente determinada. Estas mediciones directas dieron la fluencia real de la roca durante las primeras 96 horas bajo tensión constante. Finalmente, se aplicaron dos modelos con el fin de conocer el comportamiento a la fluencia a largo plazo de las rocas. El código CEB-FIP, originalmente definido para el hormigón, se adaptó a la roca estudiada por medio de la selección de valores específicos para las variables utilizadas en el código. Además, se estableció un modelo reológico con diferentes celdas de Kelvin. Ambos modelos se ajustaron para las medidas de deformación reales obtenidas durante las pruebas de laboratorio.

\subsection{Ultrasonidos}

Las ondas ultrasónicas se midieron utilizando un equipo emisor-receptor de señal (Panametrics-NDT 5058PR) acoplado a un osciloscopio (Tektronix TDS-3012B), que registra y digitaliza formas de onda, lo que permite su manipulación y almacenamiento. Se utilizaron dos tipos diferentes de transductores Panametric: un par no-polarizado y un par S-polarizado (ondas S). El primer par fue utilizado con el fin de emitir-recibir la onda ultrasónica y a partir de ahí estudiar y cuantificar el tiempo utilizado por la onda en recorrer el material. El segundo par de transductores ultrasónicos se empleó exclusivamente para medir la velocidad de propagación de la onda S. Se utilizó un medio de acoplamiento visco-elástico para lograr un buen acoplamiento entre el transductor y la muestra. La frecuencia de ambas parejas de transductores es de $1 \mathrm{MHz}$. Se han calculado tres parámetros ultrasónicos a partir de cada forma de onda registrada: velocidad de las ondas $\mathrm{P}(\mathrm{Vp})$; velocidad de las ondas S (Vs); y atenuación espacial $\left(\alpha_{\mathrm{s}}\right)$. La velocidad de creep of concrete, and model variables were adapted to specific characteristics of the rock type. The comparison between the results obtained from both procedures (short-term tests and long-term models) allows authors to establish the rock strain under constant stress at very long periods of time.

The orientation of stratification planes in the blocks were taken into account when drilling the rocks, so that these stratification planes are perpendicular to the cylinder axis in the cylindrical samples obtained.

10 cylindrical samples of $54 \mathrm{~mm}$ diameter and $100 \mathrm{~mm}$ height were obtained for petrophysical and mechanical tests (ultrasounds, porosity and density, strength and creep under constant stress). Firstly, petrographic and mineralogical characterization was carried out. Secondly, rock strength was obtained from uniaxial compressive strength test (18). Thirdly, strains measurements were carried out on rock samples under constant stress, which was fixed as $45 \%$ of the previously determined strength. These direct measurements allowed calculating the real rock creep during the first 96 hours under constant stress. Finally, two models were applied in order to estimate the long-term creep behaviour of rocks. The CEBFIP code, originally defined for concrete, was adapted to the studied rock by means of the selection of specific values for the variables used in the code. Furthermore, a rheological model was established with different Kelvin cells. Both models were adjusted to the real and direct strain measurements obtained during the laboratory test periods.

\subsection{Ultrasounds}

Ultrasonic waves were measured using a signal emitting-receiving equipment (Panametrics-NDT 5058PR) coupled to an oscilloscope (TDS 3012B-Tektronix), which acquires and digitalises waveforms allowing them to be displayed, manipulated and stored. Two different kinds of Panametric transducers were used: a non-polarized transducer couple and a S-polarized transducer couple. The first couple was used in order to acquire the ultrasonic waveform and thereafter to study and quantify it in time-domain. The second ultrasonic transducer couple was employed exclusively to measure the S-wave propagation velocity. A visco-elastic couplant was used to achieve good coupling between the transducer and the sample. The frequency of both transducer couples is centred in $1 \mathrm{MHz}$. Three ultrasonic parameters were computed from each registered waveform: ultrasonic $P$ wave velocity (Vp); ultrasonic S-wave velocity (Vs); and spatial attenuation $\left(\alpha_{\mathrm{s}}\right)$. P-wave velocity $(V p)$ is the most 
las ondas $\mathrm{P}(\mathrm{Vp})$ es el parámetro ultrasónico más ampliamente utilizado, y se determina por la relación entre la longitud de la muestra y el tiempo de tránsito del pulso. $\alpha_{\mathrm{s}}$ cuantifica la pérdida de energía durante la propagación de las ondas a través de un material. Esta cuantificación se realizó por comparación de la amplitud de la señal emitida por el sensor del transmisor y la amplitud de la registrada en la señal recibida por el sensor receptor (19). Por otra parte, la atenuación espacial se normalizó con respecto a la distancia entre los sensores de transmisor y receptor. $\alpha_{\mathrm{s}}$ se calculó según la ecuación [1]:

$$
\alpha_{S}\left(\frac{d B}{c m}\right)=\frac{20 \log \left[\frac{A g}{A_{m x}}\right]}{L}
$$

donde $A_{e}$ es la amplitud máxima emitida por el sensor transmisor $A_{m x}$ es la amplitud máxima (en valores absolutos) registrada por el sensor receptor, y $L$ es la longitud de la muestra.

\subsection{Resistencia a compresión uniaxial}

Las muestras de roca se secaron en un horno a $105^{\circ} \mathrm{C}$ durante 24 horas y se sometieron a la prueba de resistencia a compresión uniaxial. Por la forma en que se extrajeron las pobretas, los ensayos de compresión se han realizado en dirección perpendicular a los planos de estratificación. Otros autores han demostrado que el control de este aspecto es importante, ya que la anisotropía del material y la colocación de la piedra en relación con la orientación de las discontinuidades, determina el comportamiento estructural en su utilización en monumentos o cimentaciones (20-22). La velocidad de carga de la prueba se estableció en $0,5 \mathrm{MPa} / \mathrm{s}$, de acuerdo con el procedimiento estándar español (18). Estos valores obtenidos de resistencia a compresión se utilizaron como referencia para establecer la carga en la prueba a tensión constante de los ensayos de fluencia realizados en dos muestras de roca adicionales, secadas en las mismas condiciones.

\subsection{Compresión uniaxial a carga constante}

Las muestras fueron ensayadas en una prensa controlada digitalmente con el fin de mantener una carga constante a lo largo de todo el período de pruebas. La medición de la deformación se hizo con galgas resistivas conectadas a un sistema de adquisición de datos Spider 8 de HBM, a través del software Catman Easy. La medición de las deformaciones axiales y transversales se realizó utilizando dos galgas axiales y dos transversales situadas en puntos de la muestra diametralmente opuestos. El proceso de carga se llevó a cabo en dos rampas (Figura 1): la primera hasta $10 \mathrm{kN}(4,3 \mathrm{MPa}$ ) (etapa 1) y la segunda hasta $40 \mathrm{kN}$ (17,2 MPa) (etapa 3) mantenidos hasta el final de la prueba. Como se ha mencionada anteriormente, el valor de carga constante utilizada en el ensayo de fluencia widely-used ultrasonic parameter and it was determined from the ratio of the length of the specimen to the transit time of the pulse. $\alpha_{\mathrm{s}}$ quantifies the energy lost during wave propagation through a material. This quantification was performed by comparing the amplitude of the signal emitted by the transmitter sensor and the amplitude recorded in the signal received by the receptor sensor (19). Moreover, spatial attenuation was normalised with respect to the distance between transmitter and receptor sensors. $\alpha_{s}$ was calculated according to equation [1]: where $A_{e}$ is the maximum amplitude emitted by the transmitter sensor and $A_{m x}$ is the maximum amplitude (in absolute values) registered by the receptor sensor, and $L$ is the length of the sample.

\subsection{Uniaxial compressive strength}

Rock samples dried in an oven at $105{ }^{\circ} \mathrm{C}$ for 24 hours were subjected to uniaxial compressive strength test. By the way in which the samples were manufactured, compression tests were performed in a perpendicular direction to the bedding planes. Other authors have shown that control of this aspect is important, since the anisotropy of material and placement of the stone in relation to the orientation of the discontinuities, are determinant in the structural behaviour of stone in monuments or foundations (20-22). The loading rate of the test was established at $0.5 \mathrm{MPa} / \mathrm{s}$, according to the Spanish standard procedure (18). These obtained compressive strength values were used as reference value for setting the constant stress tests (the two creep tests) performed over two additional rock samples dried in the same conditions.

\subsection{Uniaxial compression at constant load}

The samples were tested using a digitally controlled press in order to maintain a constant load along the whole testing period. The strain measurement was made with resistive strain gauges connected to a data acquisition system Spider 8 of HBM, using Catman Easy software. The measurement of axial and transverse strains was performed using two axial and two transverse gauges located opposite each other. The loading process was conducted in two stages (Figure 1): the first up to $10 \mathrm{kN}$ (4.3 MPa) (stage 1) and the second up to $40 \mathrm{kN}$ (17.2 MPa) (stage 3) kept constant until the end of the test. As it was aforementioned, the constant load value used in the creep test was stated by preliminary tests, so that the final stress, kept constant during the test, was 
se obtuvo mediante ensayos preliminares, de modo que la tensión final, mantenida constante durante la prueba, fue del $45 \%$ de la resistencia a compresión uniaxial. Las pruebas se realizaron en una sala de termo-regulada a una temperatura de $25 \pm 2{ }^{\circ} \mathrm{C}$. Este rango de temperatura asegura que nos mantengamos en la zona plana de la curva de corrección de las galgas utilizadas (que corresponde a corrección nula).
$45 \%$ of the uniaxial compressive strength. Tests were performed in a thermo-regulated room with temperature of $25 \pm 2{ }^{\circ} \mathrm{C}$. This temperature range ensures that tests conditions remain in the flat zone of the correction curve of the used gauges (that is no correction required).

Figure 1. Loading process

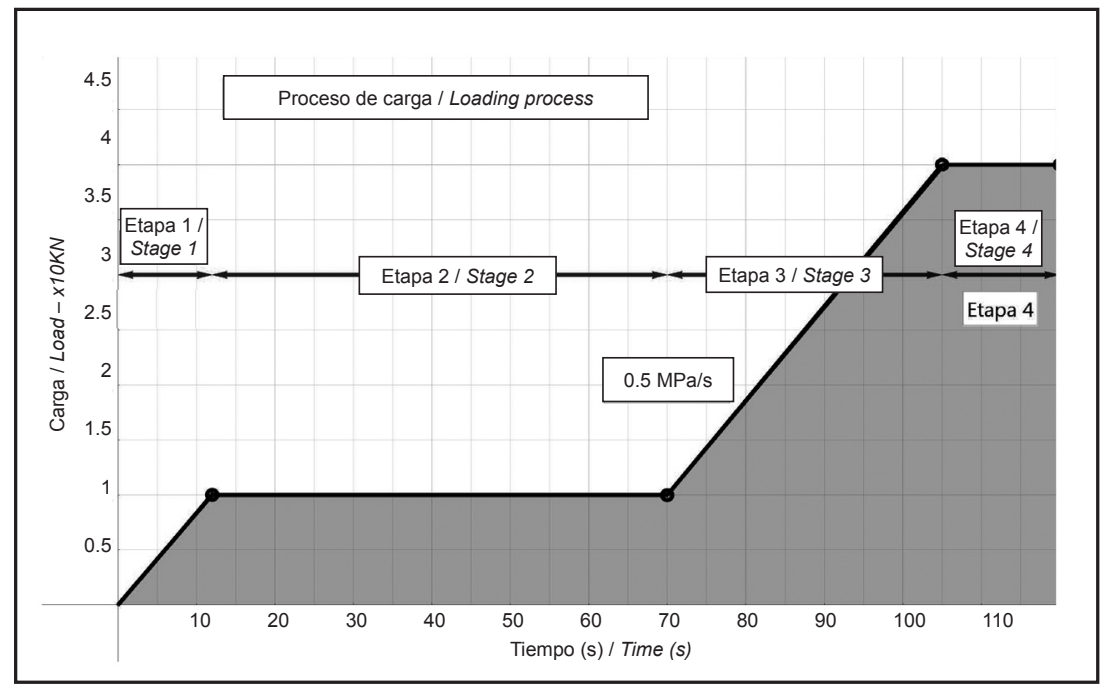

Figura 1. Proceso de carga.

Figure 1. Loading process.

\section{RESULTADOS EXPERIMENTALES}

\subsection{Petrografía y mineralogía}

La composición mineralógica de la roca en polvo fue analizada por difracción de rayos $\mathrm{X}$. Los datos se recogieron e interpretaron utilizando el paquete de software XPowder (23). El procedimiento de búsqueda de coincidencia cualitativa se ha realizado con la base de datos de ICDD-PDF2. Los componentes principales son la calcita $(70 \%)$, dolomita rica en hierro $(25 \%)$, cuarzo (5\%) y trazas de minerales de arcilla (illita). Desde un punto de vista petrográfico, la roca corresponde a una biocalcarenita muy porosa clasificada como Grainstone según Dunham (24). Texturalmente, esta roca presenta aloquímicos abundantes, por lo general de menos de $2 \mathrm{~mm}$ de tamaño, aunque también se encuentran bandas de varios tamaños de grano. Dentro de la gran variedad de briozoos fósiles, foraminíferos, algas rojas, fragmentos de equinodermos (placas y radiolas) son los más abundantes. La fracción ortoquímica corresponde principalmente a micrita (25). La roca estudiada presenta valores medio-altos de porosidad abierta $(20,0 \pm 2,0 \%)$ y una densidad aparente de $2,16 \pm 0,04 \mathrm{~g} / \mathrm{cm}^{3}$ (según la Norma UNE-EN 1936: 2007) (26).

\section{EXPERIMENTAL RESULTS}

\subsection{Petrography and mineralogy}

The mineralogical composition of rock was analyzed by powder X-ray diffraction. Data were collected and interpreted using the XPowder software package (23). The qualitative search-matching procedure was based on the ICDD-PDF2 database. The main components are calcite (70\%), iron-rich dolomite (25\%), quartz (5\%) and traces of clay minerals (illite). From a petrographical point of view, the studied rock corresponds to a very porous biocalcarenite classified as Grainstone according to Dunham (24). Texturally, this rock presents abundant allochemicals, generally less than $2 \mathrm{~mm}$ size, although bands of various grain sizes can be found. Within the great variety of fossil bryozoans, foraminifera, red algae, echinoderms fragments (plates and radiolas) are the most abundant. The ortochemical fraction corresponds mainly to micrite (25). The studied rock presents medium-high values of open porosity $(20.0 \pm 2.0 \%)$ and a bulk density of $2.16 \pm 0.04 \mathrm{~g} / \mathrm{cm}^{3}$ (according to standard UNE-EN 1936: 2007) (26). 


\subsection{Ultrasonidos}

La Tabla 1 muestra las velocidades de propagación de las ondas $\mathrm{P}$ y $\mathrm{S}\left(V_{\mathrm{p}}\right.$ y $\left.V_{\mathrm{s}}\right)$, el coeficiente de Poisson dinámico $\left(v_{d}\right)$, el módulo de Young dinámico $\left(E_{\mathrm{d}}\right)$ y la atenuación espacial $\left(\alpha_{e}\right)$ obtenidas en los ensayos.

\subsection{Ultrasounds}

Table 1 shows the $P$ and $S$ waves velocities propagation values $\left(V_{p}\right.$ and $\left.V_{p}\right)$, the dynamic Poisson's ratios $\left(v_{d}\right)$, the dynamic Young's modules $\left(E_{\mathrm{d}}\right)$ and the spatial attenuation $\left(\alpha_{\mathrm{e}}\right)$ obtained in the tests.

Tabla 1 / Table 1

Propagation velocities (Vp and Vs), dynamic modulus ( $v d$ and Ed) and spatial attenuation ( $\alpha \mathrm{e}$ ). Velocidades de propagación ( $V p$ y Vs), módulos dinámicos ( $v d$ y Ed) y atenuación espacial ( $\alpha e$ ).

\begin{tabular}{|c|c|c|c|c|c|}
\hline \multirow[b]{2}{*}{ Ejemplo / Sample } & \multirow{2}{*}{$\begin{array}{c}\begin{array}{c}\text { Ondas } P / \\
P \text { Waves }\end{array} \\
V_{p}\end{array}$} & \multirow{2}{*}{$\begin{array}{c}\text { Ondas S I } \\
\text { S Waves } \\
V_{s}\end{array}$} & \multicolumn{2}{|c|}{ Módulos dinámicos / Dynamic modulus } & \multirow{2}{*}{$\begin{array}{c}\text { Atenuac. / ATT. } \\
\alpha_{\varepsilon}\end{array}$} \\
\hline & & & $\mathbf{V}_{\mathbf{d}}$ & $E_{d}$ & \\
\hline Probeta / test & $\left(\mathrm{Km} . \mathrm{s}^{-1}\right)$ & $\left(\mathrm{Km}_{\mathrm{s}} \mathrm{s}^{-1}\right)$ & & (GPa) & (dB.cm-1) \\
\hline 1 & 3.68 & 2.17 & 0.24 & 24.47 & 3.24 \\
\hline 2 & 3.87 & 2.32 & 0.22 & 28.85 & 2.94 \\
\hline 3 & 3.85 & 2.24 & 0.24 & 27.03 & 3.34 \\
\hline 4 & 3.72 & 2.18 & 0.24 & 25.20 & 3.44 \\
\hline 5 & 3.84 & 2.14 & 0.28 & 24.50 & 3.43 \\
\hline 6 & 3.80 & 2.17 & 0.26 & 25.14 & 3.72 \\
\hline 7 & 3.86 & 2.02 & 0.31 & 23.07 & 5.58 \\
\hline 8 & 3.80 & 2.27 & 0.22 & 27.13 & 3.43 \\
\hline 9 & 3.96 & 2.34 & 0.23 & 29.95 & 3.23 \\
\hline 10 & 3.90 & 2.34 & 0.22 & 29.42 & 3.30 \\
\hline Media / Average & $3.83 \pm 0.08$ & $2.22 \pm 0.10$ & $0.25 \pm 0.03$ & $26.48 \pm 2.24$ & $3.56 \pm 0.70$ \\
\hline
\end{tabular}

Los valores de velocidad obtenidos corresponden a un rango "Medio" (27). Por otra parte, atendiendo a la clasificación de Farmer (28), se puede afirmar que los módulos dinámicos medidos son típicos de una calcarenita muy porosa con un bajo grado de cementación.

\subsection{Compresión uniaxial}

\subsubsection{Resistencia a compresión uniaxial}

El valor medio obtenido para la resistencia a compresión uniaxial es de 37,88 2,64 MPa. De acuerdo con este valor, esta roca está incluida en la clase $R_{2}$ (Roca Moderadamente Débil) según la clasificación de la ISRM (29).

\subsubsection{Fluencia bajo carga constante}

La Figura 2 muestra el total de deformación axial medida en la muestra-1, incluyendo tanto las deformaciones instantáneas como diferidas. La Figura 3 muestra la deformación debida sólo a la fluencia. La deformación instantánea se ha restado de la deformación axial total. El módulo de Young $\left(E_{\mathrm{r}}\right)$ y el coeficiente de Poisson ( $v$ ) han sido calculados con las ecuaciones [2] y [3].
The obtained velocity values correspond to a " Medium" velocity range (27). Furthermore, attending to Farmer's classification (28), it can be stated that the measured dynamic modules are typical of a very porous calcarenite with a low cementation degree.

\subsection{Uniaxial compression}

\subsubsection{Uniaxial compressive strength}

The obtained average value of rock uniaxial compressive strength was 37.88 $\pm 2.64 \mathrm{MPa}$. According to this value, this rock is included in the $R_{2}$ class (Moderately Weak Rocks) attending to the ISRM classification (29).

\subsubsection{Creep under constant load}

Figure 2 shows the total measured axial strain in sample-1, including both instantaneous and deferred deformations. Figure 3 shows the strain only due to creep. Notice that instantaneous strain has been subtracted from total axial strain. Young modulus $\left(E_{\mathrm{r}}\right)$ and Poisson's ratio (v) were calculated from equations. [2] and [3]:

$$
\begin{aligned}
& \mathrm{E}_{\mathrm{r}}=\frac{\sigma}{\varepsilon_{\mathrm{X}}} \\
& \mathrm{v}=\frac{\varepsilon_{\mathrm{t}}}{\varepsilon_{\mathrm{X}}}
\end{aligned}
$$


Donde $\sigma$ es la tensión axial, y $\varepsilon_{\mathrm{x}}$ y $\varepsilon_{\mathrm{t}}$ las deformaciones unitarias axiales $y$ transversales respectivamente.
Where $\sigma$ is the axial stress and $\varepsilon_{\mathrm{x}}$ and $\varepsilon_{\mathrm{t}}$ the unitary axial and transversal strain respectively.

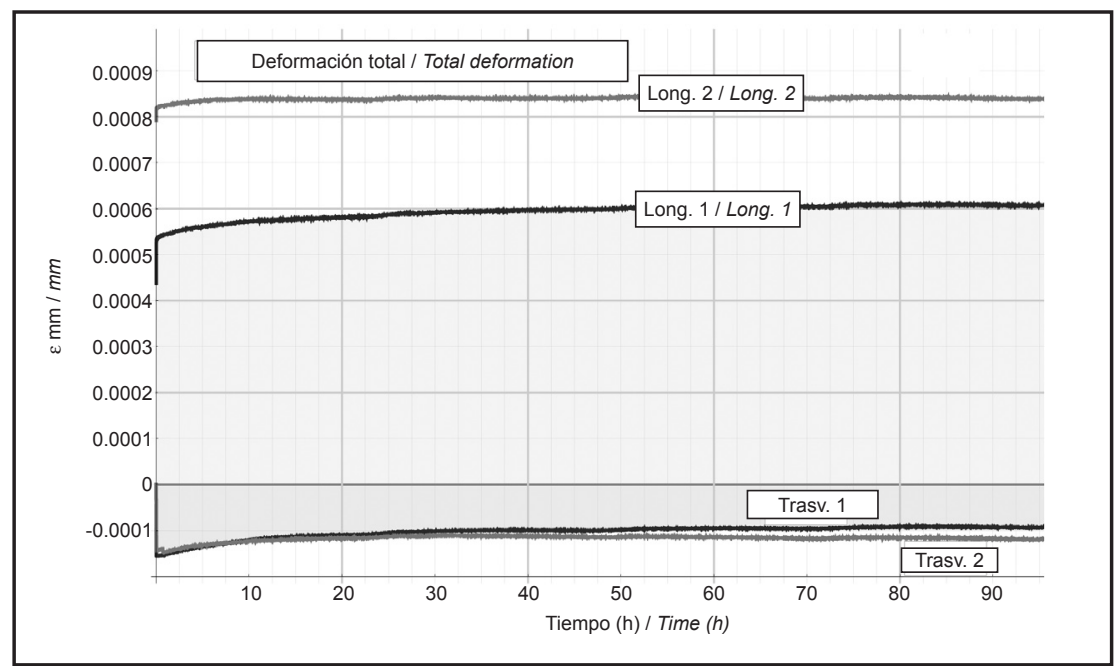

Figura 2. Deformación total de Probeta-1.

Figure 2. Total strain of Sample-1.

Los valores medios de $\mathrm{Er}$ y $v$ son $24,46 \pm 1,43 \mathrm{GPa}$ y $0,21 \pm 0,01$ respectivamente. Normalmente, en materiales pétreos como el hormigón, el módulo de elasticidad dinámico es 20, 30 y $40 \%$ más alto que el módulo estático para hormigones de baja, media y alta resistencia, respectivamente (30). Sin embargo, para la roca débil estudiada, el módulo dinámico es sólo un $8,2 \%$ mayor que el módulo estático.

\section{MODELOS (AJUSTE ANALÍTICO)}

\subsection{Modelo CEB-FIP}

El código modelo CEB-FIP (13) permite cuantificar la fluencia lenta del hormigón. La función de fluencia $(\varnothing)$ definida en el código, una vez sintetizada la información contenida en sus diversas secciones, puede ser escrita como en la ecuación [4].
The average values of Er and $v$ are 24.46 $1.43 \mathrm{GPa}$ and $0.21 \pm 0.01$ respectively. Usually, on stony materials such as concrete, the dynamic modulus of elasticity is 20, 30 and $40 \%$ higher than the static modulus for low, medium and high strength concretes, respectively (30). However for the studied low strength rock, dynamic modulus is only $8.2 \%$ higher than the static modulus.

\section{MODELLING (ANALYTICAL FITTING MODELS)}

\subsection{CEB-FIP Model}

The CEB-FIP model code (13) allows quantifying concrete creep. The creep function ( $\varnothing$ ) defined in the CEB-FIP code, once synthesized the information contained in its sections, can be written as in equation [4].

$$
\begin{gathered}
\phi\left(t, t_{0}, R H, h\right)=\left(1+\frac{1-\frac{R H}{100}}{0.1+h^{\frac{1}{3}}}\left(\frac{35}{f 28}\right)^{0.7}\right)\left(\frac{35}{\mathrm{f} 28}\right)^{0.2}\left(\frac{16.8}{f 28^{\frac{1}{2}}}\right) \frac{1}{0.1+t_{0}^{0.2}} \times \\
\times\left(\frac{t-t_{0}}{1.5 h\left(1+\left(\frac{1.2 R H}{100}\right)^{18}\right)+250\left(\frac{35}{\mathrm{f} 28}\right)^{0.5}+\left(t-t_{0}\right)}\right)^{0.3}
\end{gathered}
$$

Donde:

- $t_{0}$ es la edad a la carga,

- $\mathrm{RH} / 100$ es la humedad relativa ambiental en $\%(100 \%$ si el hormigón no puede intercambiar humedad con el medio).
Where:

- $t_{0}$ is the age at loading,

- $R H / 100$ is the ambient relative humidity \% (100\% if the concrete cannot exchange humidity with the environment) 
- $\mathrm{h}$ es el factor de forma-dimensiones en $\mathrm{mm}$ (2 x Área / Perímetro).

- $\quad$ f28 es la Resistencia a compresión uniaxial a 28 días.

De esta forma, la fluencia $(\varnothing)$ viene dada por la ecuación [5]:
- $h$ is the sample form-dimensions factor in $\mathrm{mm}$ ( $2 \times$ Area / Exposed Perimeter)

- $f 28$ is the uniaxial compressive strength at 28 days

$$
\epsilon(t)=\frac{\sigma_{t 0}}{E_{28}} \phi(t, t 0, R H, h)
$$

Donde:

- $\sigma_{\mathrm{t} 0}$ es la tensión constante aplicada,

- $\mathrm{E}_{28}$ es el modulo de Young a los 28 días.

Con el fin de aplicar el modelo de CEB-FIP a un material rocoso se consideró $t_{0}=10.000$ días. De ese modo la roca se asemeja a un hormigón muy antiguo, en el que las características mecánicas no varían con el tiempo en ausencia de otras variables. La elección de 10.000 días es arbitraria, aunque se asume que a esta edad el hormigón considerado ha alcanzado el 98,9\% de su resistencia a compresión y el 99,5\% del módulo de elasticidad, con respecto a los máximos esperables según los modelos contemplados en el código CEB-FIP. Para la aplicación del modelo CEB-FIP se ha seleccionado un hormigón con una resistencia a compresión uniaxial similar a la de la roca (hormigón tipo H01). Sus características se resumen en la Tabla 2. Estas características se han obtenido usando un ajuste por mínimos cuadrados, de modo que la fluencia del hormigón a lo largo de las primeras 96 horas, de acuerdo con el modelo, se adaptara a los resultados experimentales obtenidos en el laboratorio con la roca estudiada.
Where:

- $\sigma_{\text {to }}$ is the applied constant stress,

- $E_{28}$ is the Young 's modulus at 28 days.

In order to apply the CEB-FIP model to a rock material it was considered $t_{0}=10000$ days. Thereby the rock resembles a very old concrete, in which mechanical characteristics do not vary over time in the absence of other variables. The 10000 days choice is arbitrary: at this age the considered concrete has reached $98.9 \%$ of its compression resistance and $99.5 \%$ of elasticity modulus with respect to the maximum values expected according to the model code CEB-FIP. A concrete with a similar uniaxial compressive strength than that of the studied rock has been selected for applying the CEB-FIP model (i.e. a concrete H01 type). The characteristics of the concrete are summarized in Table 2. These features of the model are set, using a least squares adjustment, so that the creep of the concrete along the first 96 hours, according to the model, fits the experimental results obtained in the laboratory for the studied rock.

Tabla 2 / Table 2

Hormigón H01 (CEB-FIP 2010).

H01 concrete (CEB-FIP 2010).

\begin{tabular}{|c|c|}
\hline Resistencia a compresión uniaxial-28 días / Uniaxial compressive strenght -28 days & $35 \mathrm{MPa}$ \\
\hline Resistencia a compresión uniaxial-10.000 días (CEB) / Uniaxial compressive strength- 10000 days (CEB) & $42 \mathrm{MPa}$ \\
\hline Módulo de Young-28 días (CEB) / Young's modulus-28 days (CEB) & $29.38 \mathrm{GPa}$ \\
\hline Módulo de Young-10.000 días (CEB) / Young's modulus-10000 days (CEB) & $32.30 \mathrm{GPa}$ \\
\hline Cemento 52.5 R / Cement 52.5 $R$ & $\mathrm{~S}=0.20$ \\
\hline Árido calizo / Limestone aggregate & $\mathrm{a}=0.9$ \\
\hline
\end{tabular}

La Figura 3 muestra la deformación por fluencia del hormigón H01 previamente definido (linea gris oscura) y los datos obtenidos de la prueba de la muestra de roca 01 (gris clara).
Figure 3 shows the creep deformation of the HO1 concrete previously defined (dark grey line) and the data obtained from the test of rock sample 01 (light grey curve). 


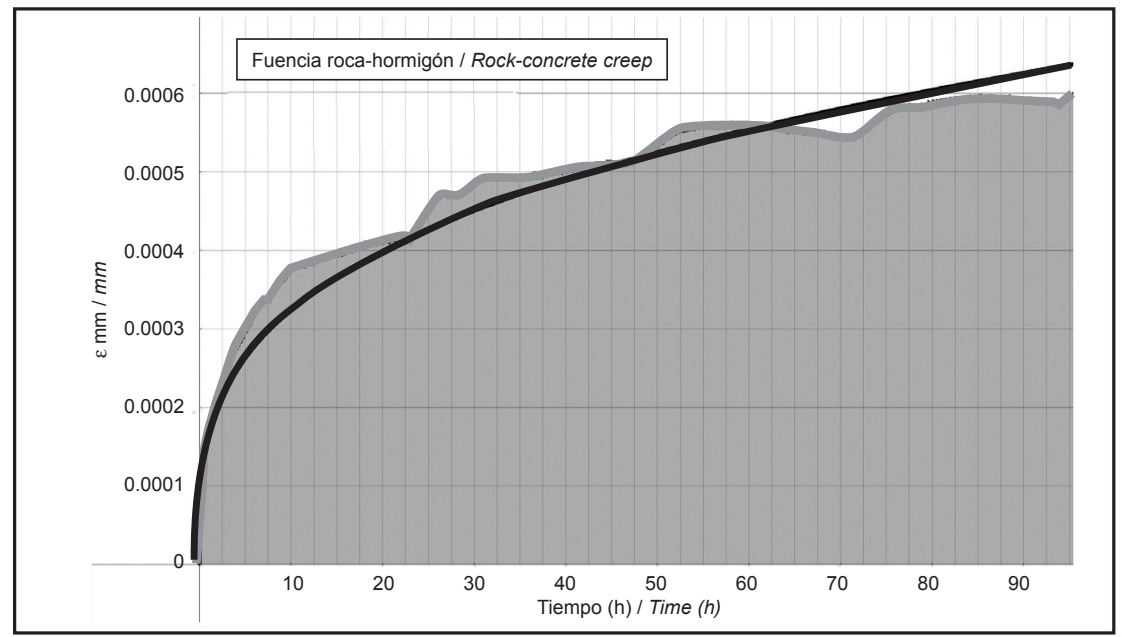

Figura 3. Curva de fluencia del hormigón H01 (gris oscuro) y la roca ensayada (gris claro). Figure 3. Creep curves of the H01 concrete (dark grey) and the tested rock (light grey).

\subsection{Modelo reológico}

También se ha utilizado en este trabajo un modelo reológico de cuatro celdas de Kelvin, con el fin de reproducir el comportamiento en fluencia de la roca estudiada. Este modelo reológico se ha ajustado a los parámetros del modelo CEB-FIB a fin de reproducir el comportamiento de la función previamente definida [5] durante un periodo de carga de 10.000 días de la siguiente forma: En primer lugar la ecuación [5] se ha discretizado con el fin de tratarla como una Tabla de datos tiempo-deformación, en segundo lugar se ha ajustado por mínimos cuadrados la función que representa el comportamiento del modelo reológico a estos datos, y como consecuencia de ello se han obtenido los parámetros del modelo $\left(E_{\mathrm{i}}\right.$ y $\left.\eta_{\mathrm{j}}\right)$. La Figura 4 muestra el modelo propuesto. Las celdas de Maxwell, que describen la fase viscoplástica, no se han considerado porque en este trabajo (y en CEB-FIP) sólo se estudia la componente de fluencia primaria o viscoelástica de la deformación (la función hiperbólica de fluencia dada en el código modelo tiende asintóticamente a un máximo a tiempo infinito lo que indica que estamos en fluencia primaria, con deformaciones a velocidad continuamente decreciente. LoS ensayos de compresión y fluencia que hemos realizado, mantienen las tensiones en el rango elástico del material en todo momento).

\subsection{Rheological model}

A four Kelvin cells rheological model has been also used in this work in order to reproduce the creep behaviour of the studied rock. This rheological model has been fitted to the CEB-FIB model parameters in order to reproduce the behaviour of the previously defined function [5] during a load period of 10000 days as follows: Firstly [5] has been discretized in order to be considered as a timestrain data series; secondly a least-square adjustment of the function that represents the behaviour of the rheological model has been performed and as a consequence the parameters of the model $\left(E_{\mathrm{i}}\right.$ and $\left.\eta_{\mathrm{j}}\right)$ have been computed. Figure 4 shows the proposed model. Notice that the Maxwell cells, that describe the viscoplastic phase, have not been considered because in this work (and in the CEB-FIP model code) only the primary or viscoelastic creep component of the deformation is being studied (the creep hyperbolic-function given in the model code asymptotically approaches a maximum at infinite time indicating that we are in primary creep, at strain speed continuously decreasing (uniaxial compressive strength and creep tests in this research, kept stress in the elastic range of the material at all times).

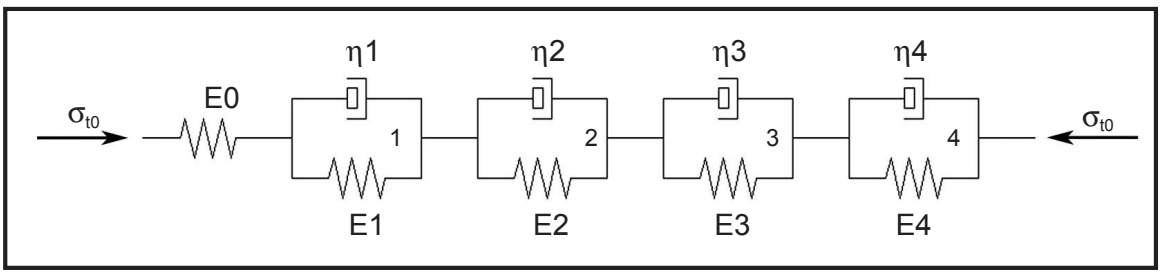

Figura 4. Modelo reológico.

Figure 4. Rheological model. 
La deformación unitaria $(\varepsilon)$ del modelo anterior se obtiene de la ecuación [6]:
The strain $(\varepsilon)$ of the previously mentioned model is given by equation [6]:

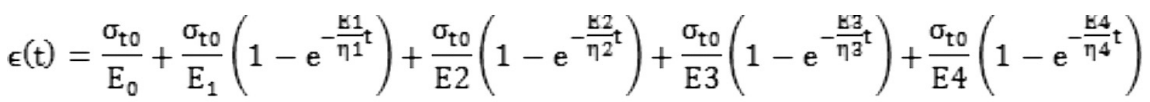

Donde:

- $\sigma_{\mathrm{t} 0}$ es la tensión constante aplicada.

- $\mathrm{E}_{\mathrm{i}}$ son los módulos de Young de los diferentes resortes del modelo.

- $\eta_{\mathrm{i}}$ son las viscosidades de los diferentes amortiguadores del modelo.

La elección del número de celdas en el modelo de Kelvin está determinada por la precisión requerida para el ajuste CEB-FIB/Modelo reológico. En este caso, el coeficiente de determinación es de $R_{2}=0,99$. Para reproducir estas deformaciones a lo largo del tiempo con la precisión requerida, se ha utilizado un modelo reológico clásico (resortes y amortiguadores), compuesto por cuatro celdas de Kelvin ( 1 a 4 en Figura 4), [6]. Los parámetros de ajuste para el modelo reológico se muestran en la Tabla 3.
Where:

- $\sigma_{\mathrm{t} 0}$ is the applied constant stress.

- $\mathrm{E}_{i}$ are the Young's modulus of the different model springs.

- $\eta_{\mathrm{i}}$ are the viscosities of the different model dampers.

Note that the choice of the number of cells in the Kelvin model is determined by the required accuracy for the CEB-FIB/Rheological model fit. In this case, the coefficient of determination is $R_{2}=0.99$. In order to assess the evolution of deformation with the required accuracy, a classical rheological model (springs and dampers) composed of four Kelvin cells (1 to 4 in Figure 4), [6] has been used. The parameters fitted to the rheological model are shown in Table 3.

Table 3 / Tabla 3

Parámetros del modelo reológico [6].

Parameters of the rheological model [6].

\begin{tabular}{|c|c|c|c|}
\hline Parámetro / Parameter & Valor (GPa) / Value (GPa) & Parámetro / Parameter & Valor (GPa.s) / Value (GPa.s) \\
\hline E0 & $1.0032 \mathrm{E}+03$ & - & - \\
\hline E1 & $8.2256 \mathrm{E}+02$ & $\eta 1$ & $1.3531 \mathrm{E}+02$ \\
\hline E2 & $2.6989 \mathrm{E}+02$ & $\eta 2$ & $2.1276 \mathrm{E}+03$ \\
\hline E3 & $1.4497 \mathrm{E}+02$ & $\eta 3$ & $3.5180 \mathrm{E}+03$ \\
\hline E4 & $2.3768 \mathrm{E}+02$ & $\eta 4$ & $6.2413 \mathrm{E}+05$ \\
\hline
\end{tabular}

\section{DISCUSIÓN}

La Figura 5 muestra la deformación en el tiempo para el modelo reológico (abajo, [6]) y la del hormigón de referencia acuerdo a CEB-FIP (arriba, [5]) para el periodo ensayado de cuatro días. En la Figura 6 los mismos parámetros para un periodo de 10.000 días.

La Figura 7 muestra el gráfico del modelo reológico y los datos experimentales obtenidos en las pruebas para la muestra-1.

Considerando los resultados obtenidos con el modelo CEBFIP y el modelo reológico, se ha propuesto una ecuación simplificada [7] para estimar el comportamiento en fluencia $(\varepsilon)$ de esta roca:

\section{DISCUSSION}

Figure 5 shows the creep time-series of the rheological model (below, [6]) and the reference concrete according CEB-FIP (arrives, [5]) for the tested period of four days. In Figure 6 the same parameters for a period of 10000 days are also plotted.

Figure 7 shows the plot of the rheological model overlaid to the experimental data obtained in the tests for sample-1.

Considering the results obtained with CEB-FIP model and the rheological model, a simplified equation [7] has been proposed for estimating the creep behaviour $(\varepsilon)$ of the rock:

$$
\mathrm{e}(\mathrm{t}, \mathrm{h})=\frac{\sigma_{\mathrm{t} 0}}{\mathrm{E}_{\mathrm{r}}}\left(\frac{1}{\mathrm{qu}_{\mathrm{u}}}\right)^{0.7}\left(\frac{519,615 \mathrm{t}}{\mathrm{t}+1707.825\left(\frac{1}{\mathrm{qu}_{\mathrm{u}}}\right)^{0.5}+41.435 \mathrm{~h}}\right)^{0.3}
$$




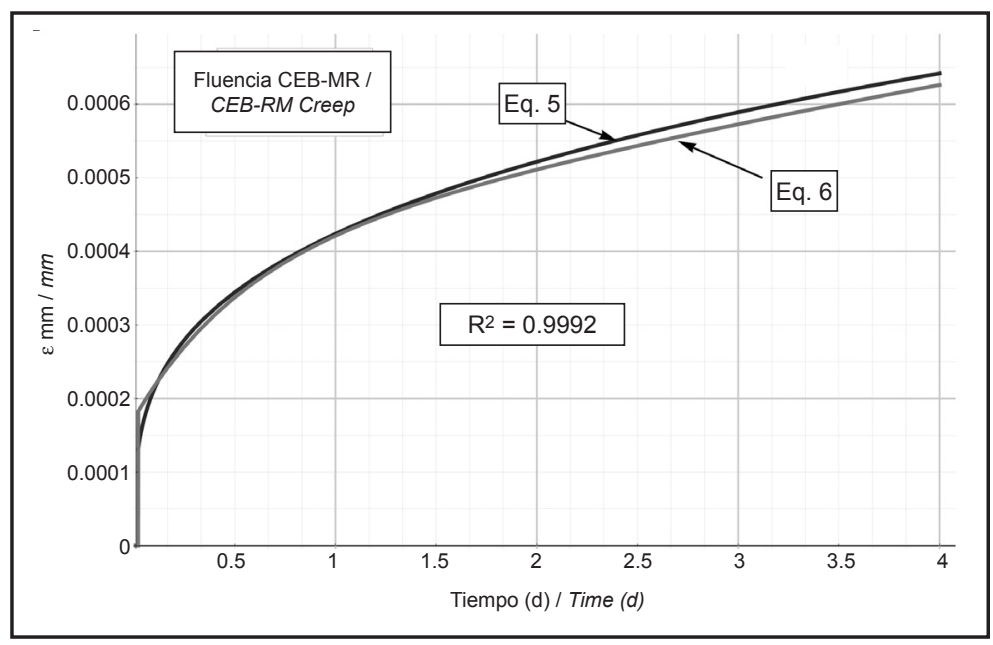

Figura 5. Modelos de fluencia del hormigón (arriba) y reológico (abajo). Figure 5. Concrete (above) and rheological (below) creep models.

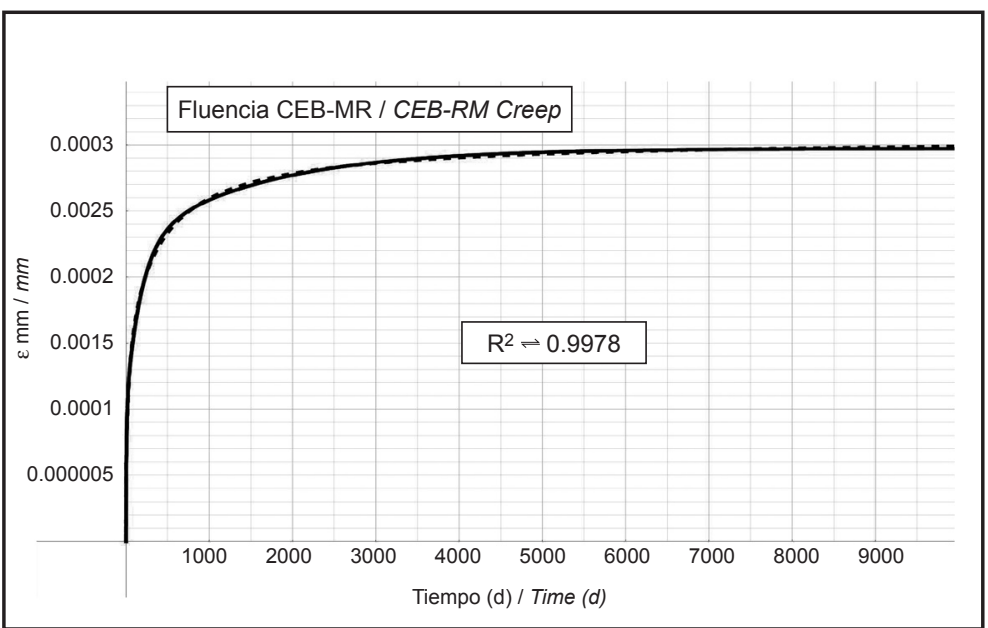

Figura 6. Modelos de fluencia del hormigón (curva discontínua) y reológico (curva contínua).

Figure 6. Concrete (dashed curve) and rheological (continuous curve) creep models.

donde:

- $\sigma_{\mathrm{t} 0}$ es la tensión constante aplicada (MPa)

- $\mathrm{E}_{\mathrm{r}}$ es el módulo de Young de la roca (MPa),

- h es el factor de forma de la pieza en $\mathrm{mm}$ (2 x Área / Perímetro),

- y $\mathrm{q}_{\mathrm{u}}$ es la Resistencia a compresión uniaxial de la roca (MPa)

La Figura 8 muestra el modelo CEB-FIB ajustado a los datos observados (arriba contínua) y la deformación calculada de acuerdo con la [7] (abajo discontínua) para los valores de $\mathrm{q}_{\mathrm{u}}=37 \mathrm{MPa} y \mathrm{E}_{\mathrm{r}}=25 \mathrm{GPa}$, que corresponden a una roca con características mecánicas similares a la estudiada, para un período de 4 días.

El modelo de fluencia propuesto en base a las propiedades mecánicas de las rocas [7], proporciona una buena aproximación al comportamiento de fluencia de la roca estudiada, en el período indicado. Los resultados muestran where:

- $\sigma_{\mathrm{t} 0}$ is the applied constant stress (MPa)

- $\mathrm{E}_{\mathrm{r}}$ is the Young 's modulus of the rock (MPa),

- $h$ is the form factor, specimen dimensions in $\mathrm{mm}$ ( $2 \times$ Area / Exposed Perimeter),

- $\quad$ and $q_{u}$ is the uniaxial compressive strength of the rock (MPa)

Figure 8 shows the CEB-FIB model fitted to the observed data (arrives continuous) and the strain computed according to [7] (below discontínua) for values of $q_{u}=$ $37 \mathrm{MPa}$ and $E_{r}=25 \mathrm{GPa}$, that correspond to a rock with mechanical characteristics similar to the one studied, for a period of 4 days.

Notice that the proposed rock creep model based on the rock mechanical properties [7] provides a good approximation to the creep behaviour of the studied rock, in the studied period. The results indicate that, although 96 


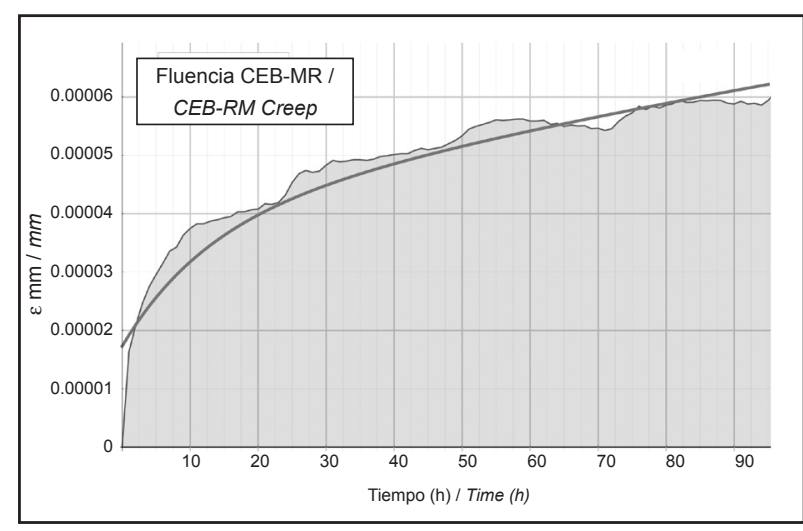

Figura 7. Modelo reológico (negro) y datos experimentales (gris).

Figure 7. Rheological model (black curve) and experimental data (grey curve).

que aunque a 96 horas la deformación de la roca es de sólo 60x10-6 mm/mm, según el modelo esto representa únicamente un $17 \%$ de la deformación por fluencia a tiempo infinito. Esto resalta la necesidad de proponer modelos precisos para predecir el comportamiento de las rocas a muy largo plazo. Por lo tanto, para confirmar la validez del modelo de fluencia propuesto en este trabajo se requieren más pruebas con diferentes condiciones de tensión. Por otra parte el modelo CEB-FIP, desarrollado experimentalmente para el hormigón, parece adecuado para ser aplicado a las rocas en el período estudiado.

\section{CONCLUSIONES}

En este trabajo se han realizado ensayos de fluencia con el fin de estudiar el comportamiento a largo plazo de una roca blanda. Se ha definido un hormigón de referencia (tipo H01) cuyo comportamiento en fluencia primaria de acuerdo con el código CEB-FIP se muestra similar al de la roca estudiada. Se ha observado que el modelo de fluencia para el hormigón de CEB-FIP, obtenido empíricamente y avalado por un considerable número de trabajos a lo largo de un amplio plazo de tiempo, puede ser aproximado mediante modelos reológicos clásicos basados en celdas de Kelvin. Las curvas de tiempo-deformación obtenidas con el modelo CEB-FIP [5] y con el modelo reológico propuesto [6] pueden ajustarse con el grado de precisión requerido. Además, en este trabajo se ha propuesto un modelo específico basado en el código CEB-FIP, adaptado a la roca débil estudiada [7] proporcionando una precisa aproximación al comportamiento real en fluencia de la roca ensayada en el período estudiado. Por último, señalar que el tipo de hormigón cuya curva de fluencia sigue de cerca el comportamiento de la roca ensayada, tiene una resistencia a compresión uniaxial en el momento de carga (es decir, el 98,9\% de la máxima resistencia esperada) prácticamente igual a la obtenida en nuestros ensayos para la roca seca. Esto sugiere la existencia de algún paralelismo entre el

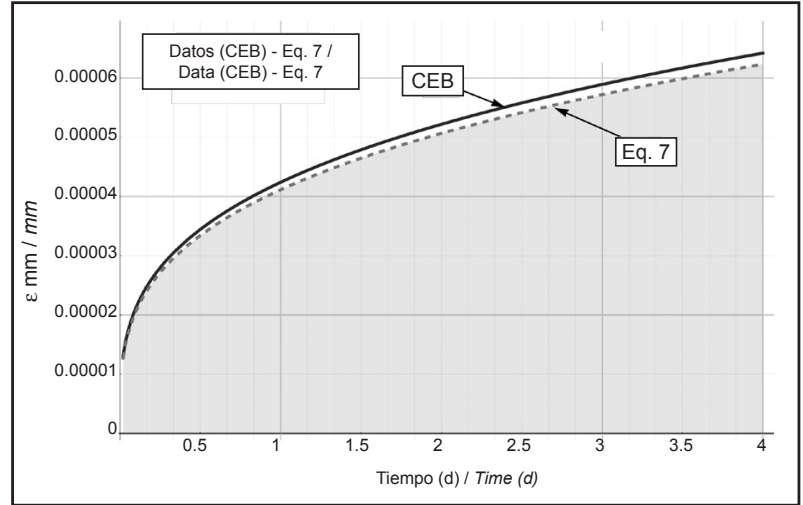

Figura 8. Modelo CEB-FIB ajustado a los datos experimentales (línea continua) y fluencia estimada con la [7] (punteada). Figure 8. CEB-FIB model fitted to the experimental data (solid curve) and creep estimated through [7] (dashed curve).

hours creep deformation of this soft rock is only $60 \times 10-6$ $\mathrm{mm} / \mathrm{mm}$, according to the model this value is only $17 \%$ of the very long-term creep deformation. This highlights the need to propose accurate models for predicting the very long-term behaviour of rocks. Therefore, the full validity of the creep model proposed on this work will require further testing with different stress conditions. Moreover, the CEB-FIP model originally and experimentally developed for concrete appears to be a suitable tool applied to rocks in the studied time period.

\section{CONCLUSIONS}

In this work creep tests have been performed in order to study the long-term behaviour of a soft rock. A pattern concrete (H01 type) whose primary creep behaviour computed according to CEB-FIP code has shown to exhibit similar creep behaviour than the tested rock has been defined. On the other hand, it was found that the creep model of CEB-FIP, empirically obtained by a considerable number of works supported over a wide time span, can be approximated by Kelvin-cells based rheological models. The results show that the timedeformation curves computed according to the CEB-FIP [5] and the proposed rheological [6] models can accurately be fitted. Furthermore, in this work a specific model based on CEB-FIP code adapted to the studied weak rock has been proposed [7] providing an accurate approximation to the real creep behaviour of the tested rock in the studied time period. Finally note that the type of concrete whose creep curve closely follows the tested rock behaviour, have a uniaxial compressive strength at the time of loading virtually equal to that obtained in the present tests for the dry rock (i.e. for the $98.9 \%$ of the maximum expected strength). This aspect suggests the existence of some parallelism between the creep behaviour of concrete and rock and as a consequence 
comportamiento en fluencia del hormigón y el de la roca, y como consecuencia la posibilidad de intentar la adaptación del código CEB-FIP para modelizar la fluencia de las rocas más allá del período estudiado.

\section{AGRADECIMIENTOS}

Los autores agradecen a la empresa U.T.E. FCC Construcción, S.A. y Enrique Ortiz e Hijos Contratistas de Obras, S.A el suministro de las muestras de roca de la excavación del túnel del TRAM. Este trabajo ha sido financiado por la Universidad de Alicante bajo los proyectos uausti11-11 y gre09-40 y por la Generalitat Valenciana bajo el proyecto gv/2011/044. suggests the possibility of adapting the CEB-FIP model to reproduce the creep behaviour of rocks beyond the tested time period.

\section{ACKNOWLEDGEMENTS}

Authors want to thank the company U.T.E. FCC Construcción, S.A. y Enrique Ortiz e Hijos Contratistas de Obras, S.A for the provided rock samples from the TRAM tunnel excavation. This work has been funded by the Universidad de Alicante under the projects uausti11-11 and gre09-40 and by the Generalitat Valenciana under the project $\mathrm{gv} / 2011 / 044$.

\section{BIBLIOGRAFÍA / BIBLIOGRAFY}

(1) Weng, M.C.; Tsai, L.S.; Hsieh, Y.M.; Jeng, F.S.: "An associated elastic-viscoplastic constitutive model for sandstone involving shear-induced volumetric deformation" , International Journal of Rock Mechanics and Mining Sciences, vol. 47, no 8 (2010), pp. 1263-1273. 10.1016/j. ijrmms.2010.08.022.

(2) Guan, Z.; Jiang, Y.; Tanabashi, Y.: "Rheological parameter estimation for the prediction of long-term deformations in conventional tunnelling", Tunnelling and Underground Space Technology, vol. 24, no 3 (2009), pp. 250-259. 10.1016/j.tust.2008.08.001.

(3) Nadimi, S.; Shahriar, K.; Sharifzadeh, M.; Moarefvand, P.: "Triaxial creep tests and back analysis of time-dependent behavior of Siah Bisheh cavern by 3-Dimensional Distinct Element Method", Tunnelling and Underground Space Technology, vol. 26, nº 1 (2011), pp. 155162. $10.1016 / j$.tust.2010.09.002.

(4) Sterpi, D.; Gioda, G.: "Visco-Plastic Behaviour around Advancing Tunnels in Squeezing Rock" , Rock Mechanics and Rock Engineering, vol. 42, no 2 (2009), pp. 319-339. 10.1007/s00603-007-0137-8.

(5) Shao, J.F.; Zhu, Q.Z.; Su, K.: "Modeling of creep in rock materials in terms of material degradation" , Computers and Geotechnics, vol. 30, no 7 (2003), pp. 549-555. 10.1016/s0266-352x(03)00063-6.

(6) Zuan, C.: "Analysis of a microcrack model and constitutive equations for time-dependent dilatancy of rocks" , Geophysical Journal International, vol. 155, no 2 (2003), pp. 601-608. 10.1046/j.1365-246X.2003.02067.x.

(7) Jandakaew, M.: "Stress-path dependency of rock salt", Rock Mechanics (2007), pp. 171-188.

(8) Berest, P.; Blum, P.A.; Charpentier, J.P.; Gharbi, H.; Vales, F.: "Very slow creep tests on rock samples" , International Journal of Rock Mechanics and Mining Sciences, vol. 42, no 4 (2005), pp. 569-576. 10.1016/j.ijrmms.2005.02.003.

(9) Fuenkajorn, K.; Phueakphum, D.: "Effects of cyclic loading on mechanical properties of Maha Sarakham salt" , Engineering Geology, vol. 112, no 1-4 (2010), pp. 43-52. 10.1016/j.enggeo.2010.01.002.

(10) Fu, Z.; Guo, H.; Gao, Y.: "Creep damage characteristics of soft rock under disturbance loads" , Journal of China University of Geosciences, vol. 19, n० 3 (2008), pp. 292-297.

(11) Anzani, A.; Garavaglia, E.; Binda, L.: "Long-term damage of historic masonry: A probabilistic model" , Constr. Build. Mater., vol. 23, no 2 (2009), pp. 713-724. 10.1016/j.conbuildmat.2008.02.010.

(12) Damjanac, B.; Fairhurst, C.: "Evidence for a Long-Term Strength Threshold in Crystalline Rock" , Rock Mechanics and Rock Engineering, vol. 43, no 5 (2010), pp. 513-531. 10.1007/s00603-010-0090-9.

(13) Afrouz, A.; Harvey, J.M.: "RHEOLOGY OF ROCKS WITHIN SOFT TO MEDIUM STRENGTH RANGE" , International Journal of Rock Mechanics and Mining Sciences, vol. 11, no 7 (1974), pp. 281-290. 10.1016/0148-9062(74)90230-7.

(14) Ma, L.-j.; Liu, X.-y.; Fang, Q.; Xu, H.-f.; Xia, H.-m.; Li, E.-b.; Yang, S.-g.; Li, W.-p.: "A New Elasto-Viscoplastic Damage Model Combined with the Generalized Hoek-Brown Failure Criterion for Bedded Rock Salt and its Application", Rock Mechanics and Rock Engineering, vol. 46, no 1 (2013), pp. 53-66. 10.1007/s00603-012-0256-8.

(15) P. Jongpradist, H.H.: "Influence of water content on and relationship between strength and creep behaviors of soft rock: experimental characterization", Rock Mechanics, Fuenkajorn \& Phien-wej (eds) (2007), pp. 80-92.

(16) Kate, J.M.; Gokhale, C.S.: "Influence of moisture on triaxial compression behaviour of soft sandstone" , Geotechnics of Hard Soils - Soft Rocks pp. 245-252., vol. 1, (1998).

(17) CEB/FIP: "Model Code 2010", Fib bulletins, vol. 55-56 (2010). 
(18) AENOR: "UNE-22950-1. Propiedades mecánicas de las rocas. Determinación de la Resistencia. Resistencia a la compresión uniaxial." , Asociación Española de Normalización y Certificación (1990).

(19) Martinez-Martinez, J.; Benavente, D.; Garcia-del-Cura, M.A.: "Spatial attenuation: The most sensitive ultrasonic parameter for detecting petrographic features and decay processes in carbonate rocks", Engineering Geology, vol. 119, no 3-4 (2011), pp. 84-95. 10.1016/j. enggeo.2011.02.002.

(20) Reyes, E.; Casati, M.J.; Gálvez, J.C.: "Study of the brickwork masonry cracking with a cohesive fracture model" , Mater. Construcc., vol. 61, no 303 (2011), pp. 431-449. 10.3989/mc.2010.57910.

(21) Fort, R.; Fernandez-Revuelta, B.; Varas, M.J.; de Buergo, M.A.; Taborda-Duarte, M.: "Influence of anisotropy on the durability of Madridregion Cretaceous dolostone exposed to salt crystallization processes" , Mater. Construcc., vol. 58, no 289-90 (2008), pp. 161-177.

(22) Alemany, R.M.E.: "Alteration of granite stone used in building construction", Mater. Construcc., vol. 57, n 288 (2007), pp. 77-88.

(23) Martin, J.D.: "Using XPowder: A software package for Powder X-Ray diffraction analysis." , D.L. GR 1001/04.ISBN 84-609-1497-6, (2004), pp. 105.

(24) Dunham, R.J.: "Classification of carbonate rocks according to depositional texture", Memoirs American Association of Petroleum Geologists (1962), pp. 108-121.

(25) Louis Cereceda, M.; del Cura, M.M.G.; Spairani, Y.; de Blas, D.: "The Civil Palaces in Gravina street, Alicante: building stones and salt weathering", Mater. Construcc., vol. 51, no 262 (2001), pp. 23-37.

(26) AENOR: "UNE-EN 1936: Métodos de ensayo para piedra natural. Determinación de la densidad real y aparente y de la porosidad abierta y total", Asociación Española de Normalización y Certificación (2007).

(27) Anon.: "Classification of rocks and soils for engineering geological mapping part I: Rock and soil materials" , Bulletin of the International Association of Engineering Geology - Bulletin de l'Association Internationale de Géologie de I'Ingénieur, vol. 19, no 1 (1979), pp. 364-371. $10.1007 / \mathrm{bf02600503.}$

(28) Farmer, I.W.: "Engineering properties of rocks" , E. and F. N. Spon Ltd.; London, vol.; no (1968),

(29) Anon.: "Classification of the strength of the rock matrix" , International Society for Rock Mechanics (1978).

(30) Rodrigues, G.S.S.; Figueiredo, E.P.: "Static modulus of elasticity of concrete measured by the ultrasonic method" , Mater. Construcc., vol. 53, no 271-72 (2003), pp. 47-58. 